\title{
The Analysis of Third-Party Funds, State Sukuk, and Corporate Sukuk Towards Financial Deepening in Indonesia
}

Mery Mary, Elis Mediawati, Fitranty Adirestuty

Economics and Islamic Finance, Universitas Pendidikan Indonesia

E-mail:_merymaryam@student.upi.edu,elis.mediawati@upi.edu ,fitranty@upi.edu

\begin{abstract}
Sharia-based financial institutions are being developed in Indonesia, especially in Islamic banking and Islamic capital market institutions. The role of financial institutions in economic growth in Indonesia is defined as financial deepening. This study examines the variables of the third party- funds, state Sukuk and corporate Sukuk towards financial deepening. The used research method in this research was the causality method with a quantitative approach. The population in this study is Islamic banking and Islamic capital markets, which are registered at the Financial Services Authority (FSA). The sampling technique was saturation sampling. The used method in this research was the descriptive-explanatory method with multiple linear regression analysis. The dependent variable in this study is financial deepening. While, the independent variable in this study is the third-party funds, corporate Sukuk, and state Sukuk. The results show that third-party funds affect financial deepening, state Sukuk affects financial deepening, and corporate Sukuk does not affect financial deepening.
\end{abstract}

Keywords. Financial Deepening, Third-Party Funds, State Sukuk, Corporate Sukuk.

\section{INTRODUCTION}

The financial sector has a crucial role in economic development in Indonesia. It could be visible from the role of finance as a source of financing for the community. It means investing in different financial instruments. The financial sector also roles as an intermediation function. The overall activities of the financial sector, which include roles as the intermediary and the mediator of investment, could produce various reliable economic activities. Therefore, job vacancy, the additional value of the economy, public economic income, and assets of the economic institution, which are essential for the financial industry in Indonesia, maybe increased (Latifah, 2016).

The role and various kinds of activities regarding the financial services sector for the economy are often referred to as the Financial Deepening (the depth of the financial sector in a particular country). Financial deepening defines as a term indicating the increase of the role and activities of the financial sector towards the economy (Latifah, 2016). The primary purpose of financial deepening is for the increase of domestic saving ratio towards income. It is due to the increase (deepen) the size of the monetary system in generating opportunities for investors to gain profit and strengthen the process of mobilization and allocation of savings. The process allows better allocation of savings to expand and diversify the financial markets and opportunities in competing for the capital market investment for the flow of savings (Sembiring \& Sukamulja, 2015). The establishment of financial services in a country shows the factual condition where financial services could suffer from deepening or financial deepening and the condition of experiencing shallowing or shallow finance (Sembiring \& Sukamulja, 2015).

The measurement of the financial services sector could be measured with some basic quantitative indicators; ratio of monetization and intermediation. The condition could distinguish the ratio if the ratio of monetization includes liquid liabilities, as an example of the sum money supply to GDP. At the same time, the intermediation ratio or the ratio of intermediaries includes several measurements based on financial institutions such as banks, which implement on credit or bank financing to stock market capitalization (Panjawa \& Widyaningrum, 2018).

According to the Director of Financial Services of the State Enterprises Ministry of Planning/Bappenas, Muhammad Cholifihani, states that the condition of the financial sector in Indonesia is still low. The condition could be shown from several indicators M2 per GDP, third-party funds per GDP, 
the private sector of domestic credit per GDP, and the assets of pension funds per GDP. Those conditions make Indonesia less than the neighboring countries of Southeast Asia, such as Singapore, Malaysia, Thailand, and the Philippines. According to Muhammad Cholifihani, the actual M2 per potential GDP is $62.60 \%$, but the realization was only $38 \%$. Thus, the financial deepening in Indonesia is still low (Alaydrus, 2019).

According to Shaw, the theory of financial deepening is indicated by the growing ratio between the sum of money supply (M2) to GDP, whereas the smaller ratio of the money supply (M2) to GDP shows the low financial sector of a country (Ruslan, 2011). The higher value of financial deepening, broader financial institutions, capital market, and money market in a particular country could happen.

There is a big necessity of strategic efforts in improving financial deepening. Some strategies to improve the financial deepening in Indonesia are conducting plans for improvement by increasing the access to the financial sector, with openness and efficiency, and increasing the rate of effective return (Ruslan, 2011).

Islamic banking functions as financial intermediaries with some strategies that could be more focused on allocating funds that have been collected (DPK) to provide better financing for investment or other necessities. The funds raised from the investment raises among customers. Therefore, they could add to the total assets of Islamic banks and improve public access to the banking sector itself, namely by performing a variety of services to the public, such as the addition of a bank unit. It may function for the banking sector itself can be enjoyed by the whole society (Latifah, 2016).

This research is intended to complement previous research, as previous research addressing financial deepening with the variables of Islamic banking and Islamic capital market as X variable is still very limited. The difference of this study places to add the study period of 2018 and uses as multiple linear regression method. The equation in this research uses the Islamic finance sector variables as variables $\mathrm{X}$ and financial deepening as variable $\mathrm{Y}$.

Based on the explanation of problems above, this research is intended in examining financial deepening in Indonesia with the title of The Analysis of Third-Party Funds, State Sukuk. Corporate Sukuk towards Financial Deepening in Indonesia year of 2014 to 2018.

\section{LITERATURE REVIEW}

\section{Financial Deepening}

Financial deepening could become a reference to encourage overall economic growth. The faster of increase regarding financial markets, will accelerate economic growth in Indonesia. On the other hand, if the financial markets are still low, it will lead to delays in Indonesia's pace of economic development (Harisuddin \& Hartono, 2019).

Schumpeter's theory mentions several hypotheses about the relationship of the financial sector to economic growth, namely:

1) Supply-leading view (finance is a decisive factor of economic growth).

2) Demand-following view (financial follows economic growth).

3) The bidirectional causality view (there is interplay role between finance and growth).

4) The independent hypothesis (financial and growth are not interconnected).

The level of financial deepening reflects the soundness of financial deepening, which is related to credit ability with interest rates on loans and deposits. Financial deepening theory defines the positive role of the financial system in economic growth in the size of the practice sector. It means that the activity of the high economic sector as an intermediary is assumed to be able to produce an efficient allocation. In development studies, financial deepening often refers to the increase in the provision of financial services with a broader selection of services geared to developing every layer in the community (Panjawa \& Widyaningrum, 2018).

The main objective of financial deepening is to increase domestic savings to income ratio in improving (deepen) the size of the monetary system to generate profit opportunities for investors. Mackinnon and Shaw introduced the financial deepening. 


\section{Third-Party Funds}

Third-Party Funds (TPF) of Islamic banks are public funds deposited in the bank of conventional and Islamic banks, which will be used as savings or investment or any other form used in Islamic banks (Arifin, 2006). Third-party funds are the primary source of bank funds as bank functions as the collection and storage of public funds for society (Siamat, 2001).

According to Muhammad (2005), third-party funds of Islamic banks has three forms, namely:

a. Courier deposits (wadi'ah), which are guaranteed safety and returns but no reward or profit.

b. Participation shares capital and risk share for general investment (mudaraba mutlaqah). The bank will pay the profits in proportion to the portfolio funded with capital.

c. Special investments (mudaraba muqayyadah), which bank acts as investment manager to acquire fee. Thus, the banks do not participate to the fully invested while investors took the risk on investment.

\section{State Sukuk}

According to Rival (2012), State Sukuk defines as an obligation with sharia-based, which the government determines. State Sukuk roles as a potential source of funds for the state development. Indonesia established the state Sukuk with Surat Berharga Syariah Negara (SBSN), which functions to publish and manage the sharia-based investment with the concept of profit-sharing (mudharabah). Therefore, it requires an underlying asset as the basis of issuance and issued with a contract. Underlying assets defines as assets that serve as the object or transaction basis related to the issuance of Sukuk. If the underlying asset is not being conducted, it would be equal to a debt. Following the law on SBSN, an underlying asset at SBSN defines as funding objects or properties of the State, which have economic value (Anik \& Pratiwi, 2017).

Sukuk is issued by legal institutions, which are established under the provisions of the legislation to issue Sukuk. The assets include state properties, which have economic value for serving the basis of state Sukuk issuance.

Based on Law No.19 of 2008, the objective of Sukuk issuance by the government is financing the state projects that the State has approved. Here are the objectives for the issuance of SBSN or state Sukuk (Anam, 2010):

1. Broadening the base of state budget financing

2. We are encouraging the growth and development of the Islamic financial market in the country.

3. We are creating a benchmark of the Islamic financial market both in the country and abroad.

4. Expanding and diversifying the investor base

5. Developing alternatives of investment instrument

6. Optimizing the utilization of State Property

7. Utilizing public funds that the conventional banking system has not vetted

\section{Corporate Sukuk}

According to the Act of National Sharia Board year 2004, Sukuk or Sharia Bonds defines as long term securities based on issued sharia principles by the issuer to the holders of Sukuk, which requires the issuer to pay the income for the holders of Sukuk in the form of profit-sharing or margin or fee. It also repays the securities fund at the due date (Endri, 2009).

Some of the benefits of Sukuk issuance for Indonesia, aside from financing the construction, but also useful for other aspects, as follows (Salsabila \& Mauluddi, 2017):

a. Infrastructure projects that absorb huge costs during this time could not be financed. However, it could be realized with the inclusion of foreign investors, especially the middle east countries.

b. Corporations could leverage Sukuk to expand the business, especially in participating in the development.

c. Capital markets and Islamic financial markets would evolve with the presence of products that are increasingly varied. The diversity of products is one of the attractions of investors, which could boost demand. The presence of Sukuk may increase the number of Islamic 
financial assets and the subsequent impact on the dynamics of the Islamic capital market. 
d. The diversification of the investor base, especially the investor base who want to invest for Sharia-based. Thus, it may optimize public funds to be achieved.

\section{PREVIOUS RESEARCH}

Firstly, paraphrasing Himmawan (2017) has depicted several independent variables such as third party funds, sharia bonds of government, corporate bonds, and the third party. Furthermore, both sharia bonds of government and corporate bonds have affected significantly to the financial deepening.

Secondly, the study of Sari (2018) has described that among the asset total, third party funds and financing have increasingly influenced financial deepening. This study has similar to the study of Sari (2018) because this uses similar variables; however, this study has utilized several variables such as sharia bonds of government and corporate bonds.

Ultimately, the research of Lukis and Ira (2018) has similar identification because this wants to illustrate the financial deepening. Meanwhile, the distinction of the subject in this study is that there are no variables of sharia bank in the research of Lukis and Ira (2018), such as third party fund and financing of sharia bank.

\section{RESEARCH METHODOLOGY \\ Overview of Research Variables \\ Financial Deepening}

Financial deepening has been identified as one of the strategies that could accelerate the pace of development if it is being implemented. However, the effect of this strategy needs to be determined and checked continuously, especially for developing countries. As a developing country, Indonesia has a character, which is not much different from other developing countries. The objective of a high economic growth rate in the development process within the limitations is faced with the problems of funding limitation to finance the infestation of development (Panjawa \& Widyaningrum, 2018).

The differences in the depth level of the financial sector may lead to different monetary policy transmission. The monetary policy serves as the utilization of transmission policies that run within the financial sector. Thus, the experienced shocks of the financial sector would affect the effectiveness of the monetary policy.

Figure 3.1 below shows the development of financial deepening in Indonesia:
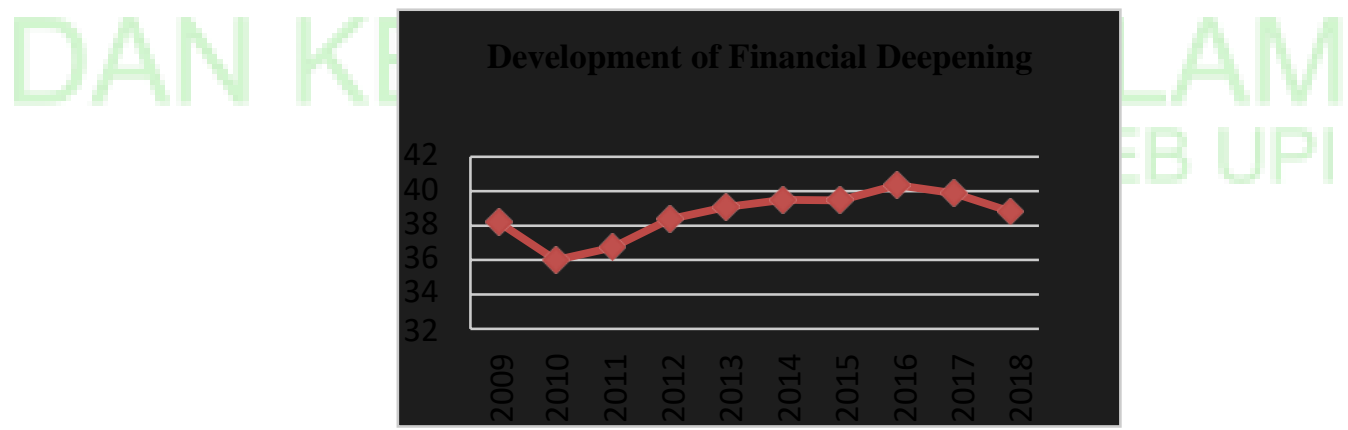

Figure 3.1 Financial Deepening Development in Indonesia

Source: World Bank 2019

The development of financial deepening in Indonesia in the last ten years could be seen in Figure 3.1. Figure 3.1 shows that financial deepening in Indonesia experienced a significant decline in 2010 by 2\%. From 2011 to 2016, the financial deepening in Indonesia has increased gradually. However, in 2017 and 2018, the financial deepening in Indonesia decreased again. The ratio of financial deepening results from the ratio of M2 / GDP or total money supply / Domestic Product. 


\section{Third-Party Funds}

Third-Party Funds (TPF) are one of the macroeconomic indicators. Third-party funds are used as the basis for determining the Statutory. Statutory Reserves are the minimum required deposit to be maintained by banks in the form of current account balances at the Bank Indonesia as stipulated by Bank Indonesia, amounting to a certain percentage of DPK. GWM is a monetary or macro-prudential instrument to manage money circulating in the community that directly affects the inflation index (Hashim, 2016).

Third-party funds of Islamic banks increase continuously and the rapidly growing market share of Islamic banking in Indonesia. Figure 3.2 below shows the development of third-party funds of Islamic banks:

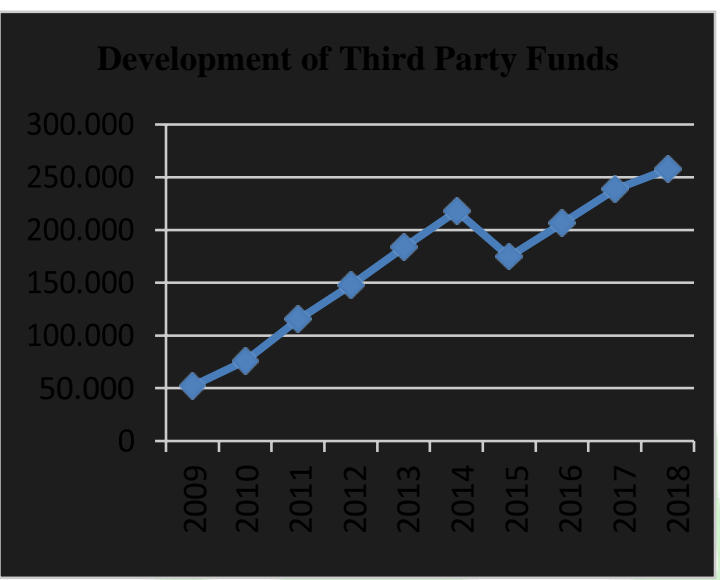

Figure 3.2 The development of Third-Party Funds

Source: The Financial Services Authority (2019)

Figure 3.2 shows the development of third-party funds of Islamic banks in the last 10 years. In 2009, third-party funds of Islamic banks reached 52.271. In 2010, third-party funds increased to 76.036. It reached 115.415 in 2011. The value increased to 147.512 in 2012. In 2013 continued to increase at 183.534. In 2014, it increased to 217.858. In 2015 third-party funds experienced a significant decline to 174.895. In 2016, the value increased again to 206.407. the third-party value increased again to 238.398 in 2017. Finally, third-party funds increased to 257.606 in 2018. In the last 10 years, third-party funds of Islamic banks experienced fluctuations. Third-party funds decreased significantly in 2015 due to the significant decrease of Islamic banking performance from the previous year, which reached 20\%, which were previously able to grow to 47,6 percent.

\section{State Sukuk}

The Sukuk was issued in 2008 after the release of Law Number 19 of 2008 which regulates by the Shariah Securities (SBSN). According to the Act of DSN-MUI Number 32 / DSN-MUI / IX / 2002. Nowadays, there are six sukuk with valid contracts in Indonesia: Mudharabah, Musyarakah, Murabahah, Salam, Istishna and Ijarah. The purpose of the government to issue the Sukuk focuses in financing the state budget, including finance construction projects. As mentioned in Article Number 4 of Law SBSN, published SBSN aims to finance the State Budget, including finance development projects. Projects, which the Sukuk could fund are the energy sector, telecommunications, transportation, agriculture, manufacturing, and housing (Pratiwi, Mainata, \& Ramadayanti, 2017). 
The following figure depicts the development of the Sukuk from the year 2009 to 2018:

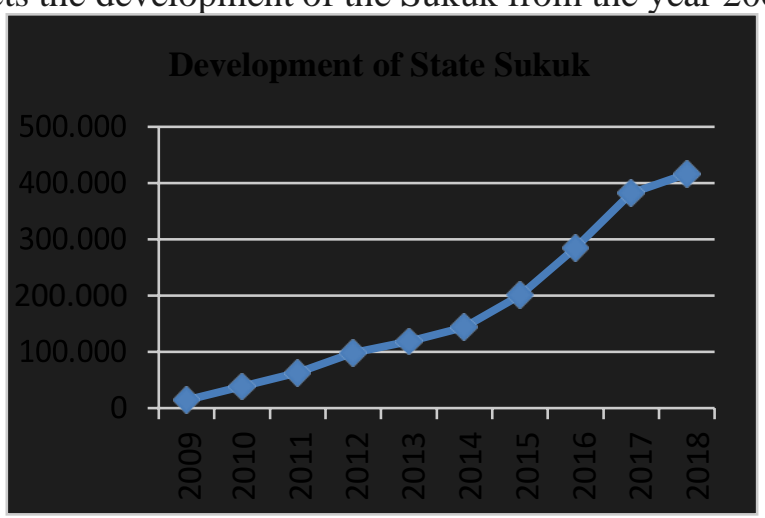

Figure 3.3 The development of State Sukuk Source: Bank Indonesia (2019)

Figure 3.3 shows that the development of Sukuk in Indonesia in the last ten years has increased very rapidly. The increasing value of Sukuk from year to year indicates the role strengthening of Sukuk in the state budget financing of which can be seen from the increasing number of Sukuk issuances State from 2009 to 2018.

The condition means the government's strategy in the issuance of the Sukuk to build the country's infrastructure is going well. Following the purpose of helping the issuance of Sukuk, which financing the State Budget, the issuance of Sukuk is used more to finance infrastructure projects compared with the financing of the budget deficit in general.

\section{Corporate Bonds}

Sukuk is a fixed-income instrument, which is issued based on Islamic principles. Corporate Sukuk revenue-based contract. The contract is stipulated in the provisions of the FSA. The contract with the basis of Islamic securities as istishna contract and contract of musyarakah (Financial Services Authority, 2018),

The first Sukuk that appeared on the market were corporate Sukuk issued by PT Indosat Tbk, OS Indosat Mudharabah. This Sukuk was issued on October 30, 2002, with an issuance value of Rp 175 billion and had a tenor for approximately five years (Beik, 2011). Following that, PT. Berlian Laju Tanker also issued Islamic Sukuk with emissions amounting to Rp.175 billion onMay 288, 2003. PT Bank Bukopin mudharabah issued Islamic Sukuk on July 100, 2003, with the issuance value of Rp. 45 billion. PT Bank Muamalat Indonesia (BMI) on July 15h, 2003, with emissions value. 200 billion. Other companies also issued the Islamic Sukuk, such as Calandra Perkasa PT on September 266, 2003, with the issuance value of Rp 60 billion, PT Bank Syariah Mandiri (BSM) on October 311, 2003, with the issuance value of Rp 200 billion, and many others (Khatimah, 2017),

The more Islamic bonds influence helping the finance development in Indonesia shows the public is increasingly interested in Shariah-based financing system and supported by the development of a prospective economic situation. As interest increases, the government should have a list of the needs for the national development program of varied investment to be offered for the public. Confidence in the government also needs to be improved for people to feel safe investing in the public sector. Significant increase in Sukuk from year to year shows that the opportunities to grow further as one investment product in Indonesia (Khatimah, 2017), 


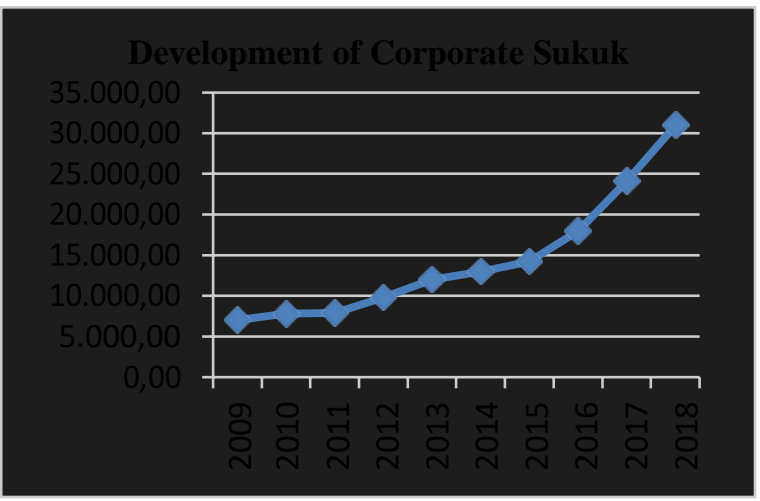

Figure 3.4 Developments of Corporate Sukuk

Source: The Financial Services Authority (2019)

Based on Figure 3.4, the trend of corporate Sukuk was fair enough as every year results in the development of increased corporate Sukuk. The growth of Sukuk is depicted from the highest level, which is found in 2018, while the lowest level in the last 10 years depicted in 2009. Although the issuance of corporate Sukuk was earlier than the State Sukuk, it could be said corporate Sukuk experience slower growth.

\section{DISCUSSION OF RESEARCH RESULTS}

\section{Research Result \\ Multiple Linear Regression Analysis}

Third-Party Funds $\left(\mathrm{X}_{1}\right)$, the Financing of Islamic Bank, Sukuk $\left(\mathrm{X}_{2}\right)$ and Sukuk Corporation $\left(\mathrm{X}_{3}\right)$ on financial deepening $(\mathrm{Y})$ was analyzed using regression analysis with multiple regression to see their influence. The analysis of regression was employed to see the influence of more than one of the independent variables on the dependent variable.

\begin{tabular}{|c|c|c|c|c|}
\hline Variable & coefficient & Std.Error & t-Statistic & Prob. \\
\hline $\mathrm{C}$ & $=\overline{2.554376}$ & $\overline{0.683942}$ & 3.734787 & 0.0004 \\
\hline PDF & 0.007433 & 0.01678 & 4.390917 & 0.0001 \\
\hline $\mathrm{SN}$ & 0.151202 & 0.06495 & 2.328985 & 0.0236 \\
\hline SK & -0.00197 & 0.01288 & -1.55408 & 0.1258 \\
\hline
\end{tabular}

Source: Data Research (2019)

Based on the data above, the processing results then was obtained from regression equation as follows:

$$
Y=\beta 0+\beta 1 X 1+\beta 2 X 2+\beta 3 X 3+\varepsilon
$$

Financial Deepening $=2.554376+0.007433$ DPK +0.151202 SN -0.00197 SK

The regression equation above have the following definitions:

1. $\beta_{0}=$ constant $=2.554376$ means that if the dependent variable of financial deepening is not influenced by any independent variable or variables DPK, Financing, State Sukuk, and Sukuk Corporation as those independent variables equal to zero. Thus, the value of financial deepening for 2.554376 rupiahs.

2. $\beta_{1}=$ coefficient of Third-Party Funds $=0.007433$ means that when third-party funds increased by $1 \%$, the financial deepening rupiah increased by 0.007433 .

3. $\beta_{2}=$ coefficient of State Sukuk $=0.151202$ means that when the state Sukuk increases by $1 \%$, the financial deepening increases by 0.151202 .

4. $\beta_{3}=$ coefficient of Corporate Sukuk $=-0.00197$ means that when Sukuk increases by $1 \%$, the financial deepening is reduced by 0.00197 rupiahs. 


\section{Hypothesis Testing}

\section{The t-test Statistics}

Ghozali (2016) states that t-test statistics show how far the influence of each independent variable is on the dependent variable. The value in the T table was obtained from the $t$ distribution table towards $\alpha$ and the degree of freedom (df), where $\mathrm{df}=\mathrm{n}-\mathrm{k}=60-4=56$, then with $56 \mathrm{df}, \alpha=5 \%$ (0.05), it was obtained the value int table of 2.00324. If the value of $\mathrm{t}>\mathrm{t}$ table, then $\mathrm{H}_{0}$ is rejected, which means that these variables influence the dependent variable.

\section{a. Effect of Third-Party Funds on Financial Deepening}

Table 3.2 Test Table of Third Party Funds to Financial Deepening

\begin{tabular}{lllll} 
variable & coefficient & Std.Error & t-Statistic & Prob. \\
\hline C & 2.554376 & 0.683942 & 3.734787 & 0.0004 \\
PDF & 0.007433 & 0.01678 & 4.390917 & 0.0001 \\
SN & 0.151202 & 0.06495 & 2.328985 & 0.0236 \\
SK & -0.00197 & 0.01288 & -1.55408 & 0.1258 \\
\hline
\end{tabular}

Source: Data Research (2019)

Table 3.2 shows that the t-statistic (4.390917) is greater than the t-table (2.00324), then $\mathrm{H}_{0}$ is rejected, or $\mathrm{H}_{\mathrm{a}}$ is accepted. The probability shows the value of 0.0001 , less than 0.05 or $5 \%$. It means that it is significant as the error zero percent under the provisions of 5\%. It can be concluded that the variable of the third-party fund has a significant influence on financial deepening. The condition shows an increase in third-party funds of $1 \%$, which will affect financial deepening for the increase to reach the value of 0.007433 .

b. The Influence of State Sukuk on Financial Deepening

Table 3.3 The t-test of State Sukuk on Financial Deepening

\begin{tabular}{|c|c|c|c|c|}
\hline Variable & coefficient & Std.Error & $\mathrm{t}$-Statistic & Prob. \\
\hline $\mathrm{C}$ & 2.554376 & 0.683942 & 3.734787 & 0.0004 \\
\hline PDF & 0.007433 & 0.01678 & 4.390917 & 0.0001 \\
\hline SN & 0.151202 & 0.06495 & 2.328985 & 0.0236 \\
\hline SK & -0.00197 & 0.01288 & -1.55408 & 0.1258 \\
\hline
\end{tabular}

Source: Data Research (2019)

Table 3.3 shows that the $\mathrm{t}$-statistic (2.328985) is more significant than the t-table (2.00424), then $\mathrm{H}_{0}$ is rejected, or $\mathrm{H}_{\mathrm{a}}$ is received. The probability knows it of 0.0236 , which is less than 0.05 or $5 \%$. It means that significance is shown as the error under the provisions of 5\%. It could be concluded that the state Sukuk variable has a significant influence on financial deepening. This condition shows that any increase in State Sukuk of 1\% will affect the increase of financial deepening to 0.151202 .

\section{c. Influence on Financial Deepening Corporate Bonds}

Table 3.4 The t-test of Corporate Sukuk to Financial Deepening

\begin{tabular}{|c|c|c|c|c|}
\hline Variable & coefficient & Std.Error & t-Statistic & Prob. \\
\hline $\mathrm{C}$ & 2.554376 & 0.683942 & 3.734787 & 0.0004 \\
\hline PDF & 0.007433 & 0.01678 & 4.390917 & 0.0001 \\
\hline SN & 0.151202 & 0.06495 & 2.328985 & 0.0236 \\
\hline SK & -0.00197 & 0.01288 & -1.55408 & 0.1258 \\
\hline
\end{tabular}

Source: Data Research (2019)

Table 3.4 shows that the t-statistic value, which is -1.55408 , tends to be smaller than the table of 2.00424. It, then, rejects or accepts $\mathrm{H}_{\mathrm{a}} \mathrm{H}_{0}$. The probability of 0.1258 is more significant than 0.05 , or $5 \%$. It means that the result is not significant. It could be concluded that the variable of corporate Sukuk does not affect the financial deepening. The condition shows that any increase in corporate Sukuk 
amounting to $1 \%$, then there is no influence on the increase or decrease in financial deepening. 


\section{Simultaneous test}

F test statistic aims to determine whether all the independent variables included in the research influence the dependent variable simultaneously. In defining an independent variable effect simultaneously for the dependent variable, it is necessary to know the $\mathrm{F}$ table compared to the $\mathrm{F}$ test statistic if statistical F value $>$ from $\mathrm{F}$ table and Prob F statistic $<0.05$, it means independent variables have a simultaneous and significant effect on the dependent variable.

The value from the $\mathrm{F}$ table value was obtained with the provisions of $\mathrm{N} 2=\mathrm{n}-\mathrm{k}, \mathrm{N} 1=\mathrm{k}-1$. Where $\mathrm{n}$ is the number of observations, and $\mathrm{k}$ is the number of independent variables plus a constant. Thus, the used value of $\mathrm{F}$ table in this study was $\mathrm{N} 2=60-4=56, \mathrm{~N} 1=4-1=3$, and $\alpha=0.05$ or $5 \%$. The obtained value of the $\mathrm{F}$ table was 2.77 .

The results of the $\mathrm{F}$ Test were obtained as follows:

Table 3.5 The Results of Test $F$

\begin{tabular}{|c|c|c|c|}
\hline R-squared & 0.853483 & Mean dependent & 5.964954 \\
\hline $\begin{array}{l}\text { Adjusted } \\
\text { red }\end{array}$ & 0.845634 & SD dependent var & 0.358906 \\
\hline SE of regression & 0.141012 & $\begin{array}{l}\text { Akaike information } \\
\text { cion }\end{array}$ & -1.015597 \\
\hline Sum squared resid & 1.113532 & Schwarz criterion & -0.875974 \\
\hline Log-likelihood & 34.46791 & $\begin{array}{l}\text { Hannan-Quinn } \\
\text {. }\end{array}$ & -0.960983 \\
\hline F-statistic & 108.7358 & Durbin-Watson stat & 0.753542 \\
\hline Prob (F-statistic) & 0.000000 & & \\
\hline
\end{tabular}

Source: Data Research (2019)

Table 3.5 shows that the value of the F statistic (108.7358) was more significant than the F table (2.77), which means an effect, and the F-statistic Prob less than 0.05, which means significant. It could be concluded that State Sukuk, Corporate Sukuk to Financial Deepening, simultaneous variables of thirdparty funds.

\section{Coefficient of determination (R2)}

Ghozali (2016) states that the coefficient of determination test aims to measure how far the model's ability is in explaining the variation of the determination coefficient. The value of the determination coefficient is between zero and one. The value of $\mathrm{R} 2$ shows that the ability of independent variables to explain the dependent variable is minimal. The determination Coefficient aims to measure the extent to which the ability of the model explaining the relationship between variables.

Table 3.6 The Result of R-Squared

\begin{tabular}{ll}
\hline R-squared & 0.853483 \\
Adjusted R-squared & $\underline{0.845634}$
\end{tabular}

Source: Research Data (2019)

Table 3.6 shows that the value of Adjusted R-squared is 0.853483 . It shows that the influence of independent variables, namely $\mathrm{X}_{1}$ (third-party funds), $\mathrm{X}_{2}$ (Corporate Sukuk), $\mathrm{X}_{3}$ (Sukuk) towards $\mathrm{Y}$ (Financial Deepening), amounted to $84.57 \%$. While the remaining $15.43 \%$ influenced by other variables outside the model that is not included in the study. 


\section{Discussion \\ The Effect on Third-Party Funds to Financial deepening}

Based on the test results, the influence between the third-party funds to financial deepening happened. It shows that an increase or decrease in third-party funds may impact financial deepening in Indonesia.

Third-party funds are customer funds deposited or entrusted by customers to the Islamic banks or Islamic business unit with a specific contract following Islamic principles to save or invest either in the form of savings, current accounts, etc. Third party-funds are relatively influential in determining the financing, which the bank will channel to the people who need money, as bank financing is still dominated by the third-party funds raised from the public. The more funds raised from the public, the more the funds will be allocated to productive financing by banks. It will help increase economic growth, and with the higher third-party funds, the economic growth in the rill sector will also increase.

The condition is by Schumpeter's theory, which states that finance-led growth or supply-leading hypothesis that explains the relationship between the financial sector deals with economic growth. This theory states that the financial sector will promote economic growth. It means that the financial sector, one of which is Islamic banking becomes intermediaries in collecting and distributing the chance to those who are in need through the efficient sources of funding, which will drive to the real economic sectors and has helped to promote economic growth (Hashim, 2016).

The results of this study confirmed the results of previous studies by Himmawan Arif (2017), Amy Latifah (2016), Muhammad As'ad Asysyfa (2017), which states that the third-party fund has positive effect on financial deepening. The more funds raised from the public, the more funds will be allocated as a loan fund that can be used for investments or loans that are productive. Thus, it will lead to more significant economic growth.

It can be concluded that third-party funding has a significant positive impact on financial deepening in Indonesia based on the findings in this study, which were associated with theoretical concepts and empirical facts from the support of previous studies.

\section{The Influence of State Sukuk on Financial Deepening}

The test results indicate that there is an influence between state Sukuk to financial deepening. It shows that an increase or decrease in the State Sukuk could affect the financial deepening in Indonesia. In this case, the State Sukuk has a crucial role in the financial state budget and infrastructure. The government should continue to work on issuing efficient States by the target to be achieved. As described in the Act of SBSN, the role of Sukuk will be sensed increasingly when the government is implementing the expansion of the budget policy to stimulate economic growth. The policy from the government to increase spending is supported by tax and non-tax receipts and other financing instruments, including state Sukuk (Latifah, 2016).

In this case, state Sukuk impacts financial deepening by Schumpeter's theory that finance-led growth or supply-leading hypothesis shows the relationship between the financial sector and economic growth. The theory states that the financial sector encourages economic growth. In this regard, the Islamic capital market as a financial intermediary acts to improve the financing of the country's infrastructure in supporting the development and the growth of economic growth through state development.

Previous research studies support the results of this study with the same results by Latifah (2016), Himmawan (2017). The results of previous studies state that if state Sukuk has a positive impact on financial deepening. The government's policy to increase state budget expenditure and infrastructure development would not only be supported by tax revenues and non-tax but also

should be supported by the instruments of Islamic finance, in this case the State Sukuk will perform its function as an instrument to support the government to promote infrastructure development in

Indonesia. Based on the findings, this study was associated with theoretical concepts and empirical facts supported by previous studies. It could be concluded that the state Sukuk has a significant positive effect on financial deepening in Indonesia. 


\section{The Influence of Corporate Sukuk on Financial Deepening}

The test results indicate that there is no influence between corporate Sukuk to financial deepening. Corporate Sukuk does not affect financial deepening. The condition is probably due to the value of corporate Sukuk, which was still low, even though corporate Sukuk appeared earlier than the State Sukuk. However, the growth is slower compared to the State Sukuk. The research result is consistent with the results of research from Ridwan (2017). It states that the Sukuk in the short term does not influence financial deepening. However, these results contrast with research results from Latifah (2016), Himmawan (2017), which states that corporate Sukuk hurts financial deepening, which means, when the Sukuk increased by $1 \%$, then the financial deepening will be in downhill or shallowing.

Some factors are not directly related to the market of liquidity Sukuk secondary (Ridwan, 2017):

a. There are still limitations in issuing the Sukuk in Indonesia, both from the number, variety, and type of contract tenor.

b. There is still a lack of understanding towards corporate Sukuk investors to trade in the secondary market.

c. Issuance of corporate Sukuk is still offered in retail to the general public but limited to institutional investors or individuals with a relatively sizeable nominal value. However, some regulations have been established to serve as the basis facilitation for the issuance of corporate Sukuk in retail.

d. The majority of corporate Sukuk investor's character is a local institutional investor such as insurance companies, pension funds, and mutual funds, which tend to buy structured in holding the maturity.

In this case, corporate Sukuk has no influence on the financial deepening relations according to Schumpeter's theory of independent hypothesis that states the financial means and growth are not interconnected. The financial is included in corporate Sukuk capital market instruments, which is not effecting if it is only increased by $1 \%$.

Corporate Sukuk has no significant effect on the financial deepening in Indonesia, which is based on the findings in this research with the association with theoretical concepts and empirical facts from previous studies.

\section{CLOSING}

\section{Conclusion}

1. The development of financial deepening in Indonesia until now has not reached the potential expectation. At the same time, the development of third-party funds experienced volatility. State Sukuk increases from year to year. Equally, with the State Sukuk, corporate Sukuk also increases every year. However, although the issuance of the corporate that state Sukuk, the development is slower.

2. Third-Party Funds have a significant influence on the financial deepening. When the third partyfunding has increased, the financial deepening in Indonesia will gain a more meaningful role on financial institutions in Indonesia for more significant economic growth in Indonesia. If the public raised more funds, more funds will be allocated as a loan fund, which could be used for investments or productive loans to lead to more significant economic growth.

3. State Sukuk has a significant effect on the financial deepening. Then, it means if the state Sukuk increased, the financial deepening would be deepened, as the Sukuk is an instrument to be used in financing the state budget and state infrastructure development. The state Sukuk is an asset to develop a country that can be the pillar for economic growth in Indonesia.

4. Corporate Sukuk does not affect the Financial Deepening. If corporate Sukuk experiences increase or decline, it does not affect the financial deepening since the growth of corporate Sukuk is slower than the State Sukuk. Corporate Sukuk is more targeted for company profit or business expansion.

\section{Suggestion}

First of all, the sharia banking must increase the third party fund for this can incline the financial deepening likewise this case require several the endeavoring should be conducted such as the bank. 
Should execute an innovation on products, to enlarge the promotion strategy with pick up method. Thus the customers do not need anymore to visit the bank to save their funds.

Secondly, the government must enhance their strategy for rising bonds market to realize the impact on economic and financial deepening, such as protecting the information transportation of bond managing. The development of product innovation, creating the primary dealer's system (PDS) of bonds, and the construction bond helpdesk.

Eventually, the following research regarding this is that the study can more reveal the variable taken and add the other macro and micro variables. Moreover, the following study can extend the period of research; hence this can accomplish the maximal result.

\section{REFERENCE}

Bank Indonesia. (2019). Retrieved July 2019, 31, from Bank Indonesia.

World Bank. (2019). Retrieved Juli 30, 2019, from World Bank.

Alaydrus, H. (2019, Januari 28). Peran Industri Jasa Keuangan Terhadap PDB Minim. Retrieved April 7, 2019, from Bisnis.com: https://ekonomi.bisnis.com/read/20190128/9/883183/peran-industrijasa-keuangan-terhadap-pdb-minim.

Anik, \& Pratiwi, I. E. (2017). Pengembangan Instrumen Sukuk Dalam Medukung Pembangunan Infratruktur. Jurnal Ilmiah Ekonomi Islam.

Arifin, Z. (2006). Dasar - Dasar Mnaajemen Bank Syariah. Jakarta: Pustaka Alvabet.

Asysyfa, M. A. (2018). Analisis Pengaruh Sektor Keuangan Syariah terhadap Financial Deepening di Indonesia Periode 2011 - 2017.

Beik, I. S. (2011). Memperkuat Peran Sukuk Negara dalam Pembangunan Ekonomi Indonesia. Jurnal Ekonomi Islam Al-Infaq, Vol. 2 No. 2, September 2011.

Endri. (2009). Permasalahan Pengembangan Sukuk Korporasi di Indonesia Menggunakan Metode Analytical Network Process (ANP). Jurnal Keuangan dan Perbankan, Vol. 13, No.3.

Ghozali, I. (2016). Aplikasi Analisis Multivariete IBM SPSS 23. Semarang: Badan Penerbit Universitas Dipenogoro.

Harisuddin, \& Hartono, D. (2019). Financial Deepening Impacts on Regional. Jurnal Ilmu Ekonomi.

Himmawan, A. (2017). Pengaruh Dana Pihak Ketiga dan Pasar Modal Syariah terhadap Financial Deepening di Indonesia.

Khatimah, H. (2017). Sukuk dan Kontribusinya dalam Pembiayaan Pembangunan Ekonomi. Jurnal Ekonomi dan Kewirausahaan.

Latifah, A. (2016). Pengaruh Sektor Perbankan Syariah Dan Pasar Modal Syariah Terhadap Financial Deepening Di Indonesia . Ekonomi Islam.

Muhammad. (2005). Manajemen Bank Syariah. Yogyakarta: UPP AMP YKPN.

Panjawa, J. L., \& Widyaningrum, I. F. (2018). Hubungan Financial Deepening dan Pertumbuhan Ekonomi : Studi Empiris Indonesia. Penelitian. 
Pratiwi , A., Mainata, D., \& Ramadayanti, R. S. (2017). Peran Sukuk Negara dalam Pembiayaan Infrastruktur . Jurnal Ekonomi dan Bisnis Islam.

Ridwan, M. M. (2017). Pengaruh Perbankan Syariah dan Pasar Modal Syariah terhadap Financial Deepening di Indonesia dan di Malaysia.

Ruslan, D. (2011). Analysis Financial Deepening di Indonesia. Journal of Indonesian Applied Economics.

Salsabila, F. D., \& Mauluddi, H. A. (2017). Pengaruh Penerbitan Sukuk Korporasi Terhadap Reaksi Pasar Modal Indonesia Periode 2002-2016. Ekspansi.

Sari, K. P. (2018). Analisis Pengaruh Perbankan Syariah terhadap Financial Deepening di Indonesia.

Sembiring, A. A., \& Sukamulja, J. S. (2015). Analisis Financial Deepening di Indonesia.

Siamat, D. (2001). Manajemen Lembaga Keuangan Edisi Ketiga. Jakarta: FEUI. 